\title{
First report of Melittobia australica Girault in Europe and new record of M. acasta (Walker) for Italy
}

\author{
Antonino Cusumano', Jorge M. González², Stefano Colazza', S. Bradleigh Vinson² \\ I Dipartimento DEMETRA, Universitá degli Studi di Palermo, Viale delle scienze, 90128 Palermo, Italy \\ 2 Texas A \& $M$ University, Department of Entomology, College Station, Texas 77843-2475, USA \\ Corresponding author: Jorge M. González (gonzalez.jorge.m@gmail.com)
}

Academic editor: N. Johnson | Received 26 January 2012 | Accepted 26 March 2012 | Published 6 April 2012

Citation: Cusumano A, González JM, Colazza S, Vinson SB (2012) First report of Melittobia australica Girault in Europe and new record of $M$. acasta (Walker) for Italy. ZooKeys 181: 45-51. doi: 10.3897/zookeys.181.2752

\begin{abstract}
Melittobia acasta and M. australica are newly recorded from Sicily, Italy, and the second species is reported in Europe for the first time. A short historical background about Melittobia parasitoid wasps, their hosts, and distribution, with emphasis in those two species is presented together with illustrations to facilitate their identification. Brief discussion about the presence and possible distribution of the species in Sicily is also included.
\end{abstract}

\section{Keywords}

Parasitoid wasp, Sceliphron spirifex, Osmia sp., Sicily, Europe

\section{Introduction}

Melittobia Westwood is a cosmopolitan genus of gregarious ectoparasitoids that primarily attack prepupae of aculeate Hymenoptera, but are also able to parasitize a wide range of hosts from the orders Coleoptera, Diptera and Lepidoptera (Dahms 1984b; González et al. 2004; Matthews et al. 2009). They are frequently associated with muddauber wasps (Sceliphron spp. and Trypoxylon spp.) but some species are frequently found parasitizing several bee species (i.e. Anthidium, Anthophora, Apis, Bombus, Ceratina, Chalicodoma, Heriades, Megachile, Osmia, Psythirus, Stelis) (González and Terán 1996; González et al. 2004; Maeta 1978; Matthews et al. 2009). 
Twelve species are known in the genus (Matthews and González 2008; Matthews et al. 2009). All Melittobia species exhibit extreme intrasexual and intersexual polymorphism, where males are blind, and brachypterous, and have highly modified antennae. Females are either brachypterous, and emerge from the pupae containing a large batch of eggs and are ready to mate, or macropterous, and capable of greater dispersal (Cusumano et al. 2010; González and Matthews 2008; Matthews and González 2008; Matthews et al. 2009; Schmieder 1933). Of these, Melittobia acasta (Walker), has been known as the only Eurasian species of Melittobia but it occurs widely in other regions of the world (Summarized by González et al. 2004). It has been reported as a dangerous threat to honeybees and/or solitary bees used as crop pollinators (See González and Matthews 2005).

Melittobia australica Girault, was described on the basis of three males and ten females that emerged from Pison spinolae Shuckard (Hymenoptera: Sphecidae) (Girault 1912). This parasitoid is a nearly cosmopolitan species that has been reported from Australia and New Zealand, several countries of Africa, Asia, North, Central and South America, including a few Caribbean islands/countries (Assem et al. 1982; Dahms 1984a; González and Matthews 2005; González and Terán 1996; González et al. 2008; Maeta 1978).

Here we confirm the presence of two Melittobia species (M. australica and M. acasta) in Italy and provide the first record of $M$. australica from Europe.

\section{Materials and methods}

Collections of trap nests and mud dauber nests were carried out during 2010 in western Sicily. Trap nests were built by pooling together about 10 pieces $(\varnothing=2-3 \mathrm{~cm}$; length $=20$ $\mathrm{cm}$ ) of reed (Arundo donax L.) that were hung on trees located both in cultivated and uncultivated fields. Nests of mud dauber wasps were collected mainly from external walls of buildings especially in areas close to water sources.

A number of Melittobia wasps emerged from trap nests colonized by Osmia bees originally placed in the Palermo University campus ( $\left.38^{\circ} 06^{\prime} 26^{\prime \prime} \mathrm{N}, 13^{\circ} 21^{\prime} 07^{\prime \prime} \mathrm{E}\right)$. The collected parasitoids were mounted and later identified.

One of several mud dauber nests constructed by Sceliphron spirifex L. (Hymenoptera: Sphecidae) collected in the town of Contessa Entellina (province of Palermo) $\left(37^{\circ} 44^{\prime} 23^{\prime \prime} \mathrm{N}, 13^{\circ} 08^{\prime} 27^{\prime \prime} \mathrm{E}\right)$, had a cell containing a prepupae of its host parasitized with Melittobia wasps. Some were collected and placed on calliphorid pupae (Calliphora sp., Diptera: Calliphoridae) to be reared, while the rest were studied and identified. The parasitoids that emerged from these cultures were studied, identified and counted (Table 1).

A thorough review of literature was done in order to corroborate that the identified species indeed constituted a new record for the country. We were unable to review other insect collections besides the one at Universitá degli Studi di Palermo, and that of an amateur entomologist in Palermo. Voucher specimens of both parasitoid species 
Table I. Melittobia australica Girault emerged from six pupae of Calliphora sp., under laboratory conditions $\left(25^{\circ} \mathrm{C} ; 75 \% \mathrm{RH}\right)$ at Dipartimento DEMETRA, Universitá degli Studi di Palermo, Sicily, Italy

\begin{tabular}{l|l|l|l|l}
\hline Host number & Males & $\begin{array}{l}\text { Brachypterous } \\
\text { females }\end{array}$ & $\begin{array}{l}\text { Macropterous } \\
\text { females }\end{array}$ & Larvae/Pupa** \\
\hline 1 & 3 & 1 & 60 & 20 \\
\hline 2 & 2 & 3 & 45 & 28 \\
\hline 3 & 2 & 1 & 11 & 82 \\
\hline 4 & 1 & 0 & 5 & 89 \\
\hline 5 & 4 & 0 & 12 & 68 \\
\hline 6 & 3 & 1 & 68 & 18 \\
\hline Total & 15 & 6 & 201 & 305 \\
\hline Mean & 2.5 & 1 & 33.5 & 50.83 \\
\hline
\end{tabular}

* These larvae/pupae died during development.

and the hosts are deposited at the TAMU insect collection, College Station, Texas, USA and at Palermo University, Palermo, Sicily, Italy.

\section{Results and discussion}

Four males and 63 macropterous females of Melittobia acasta were collected (and mounted) from a cell of Osmia sp. inside a trap nest.

A total of one male and 376 females of $M$. australica emerged from a Sceliphron spirifex prepupa. It is worth noting that the factitious host Calliphora pupae appear to be highly nutritious and large allowing the development of brachypterous females (Table 1). From six cultures established using Calliphora pupae (four females/fly pupae) as hosts, fifteen males of $M$. australica, as well as six brachypterous females, 201 macropterous females and 305 pupae/larvae emerged (see Table 1).

The easiest way to separate Melittobia acasta and M. australica is by examining male specimens under a magnifying glass $(10 \times-20 \times)$ or a microscope. Males of $M$. acasta are 1.3-1.5 mm long, light brown or amber in color (Figure 1a); antennal scape has a cupshaped depression, the distal region of the scape is strongly oblique with a broad excavation (Figure 2a) (Dahms 1984a; González and Terán 1996). Males of M. australica are 1.1-1.3 mm long, light amber in color and have an antennal scape with a deep ventral longitudinal groove (Figures 1b, 2b) (Dahms 1984a; González and Terán 1996). In order to identify species using females we recommend following Dahms (1984a).

Even though the North American species Melittobia chalybii Ashmead was once mentioned in an European country (Denmark) by Holm (1960), it was later clarified that the species was actually M. acasta (Holm and Skou 1972; González and Matthews, 2005). Otherwise, all reports we had been able to find of the presence of Melittobia in European countries, indicate that the species found was always $M$. acasta (González and Matthews 2005; González et al. 2004). Thus it was not surprising that the first 


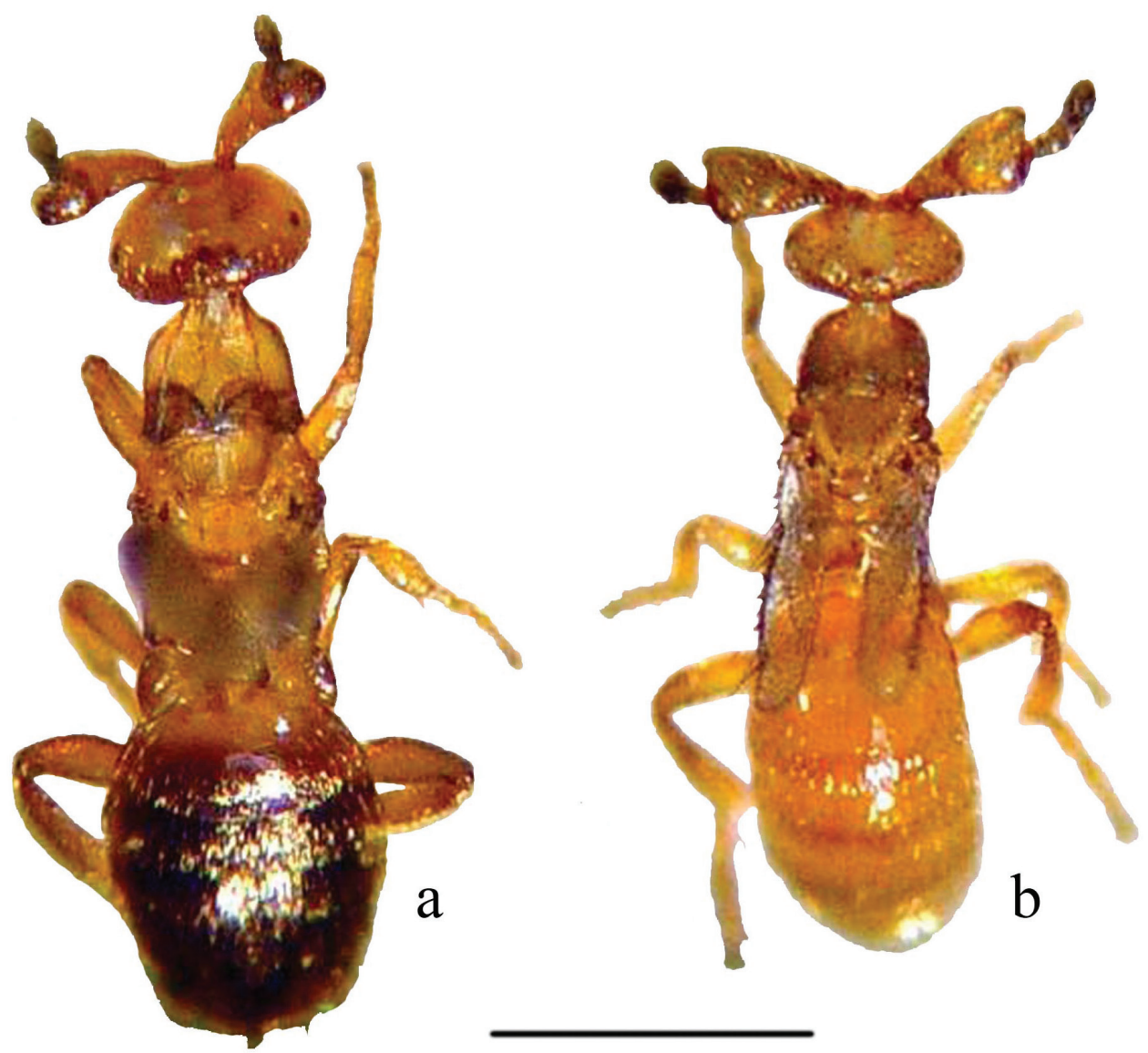

Figure I. Males of Melittobia parasitoid wasps: a M. acasta b $M$. australica. Scale: $0.5 \mathrm{~mm}$

Melittobia we encountered in Sicily was $M$. acasta. Since the species was encountered in Palermo, a major port-city in the island, we might suspect that the species found its way to Sicily through the many ships that come from many lands to this place. Since M. acasta is widely distributed in Europe and Asia, we might even speculate that its invasion of Sicily could have occurred centuries ago.

Even though Melittobia australica is a nearly cosmopolitan species, it has never been reported from Europe until now. The finding of this species in the town of Contessa Entellina, located about 80-90 km from the port of Palermo raises an interesting question: how long has it been in Sicily? Since the place where we found $M$. australica in Sicily is in the interior of the island, we might suspect that the species is widely distributed on the island. It is important to note that several species of bees and wasps known from Sicily (Incalterra et al. 2003; Rasmont et al. 2008; SchmidEgger 2003) are suitable hosts for both Melittobia wasps found, helping them to easily establish on the island. 

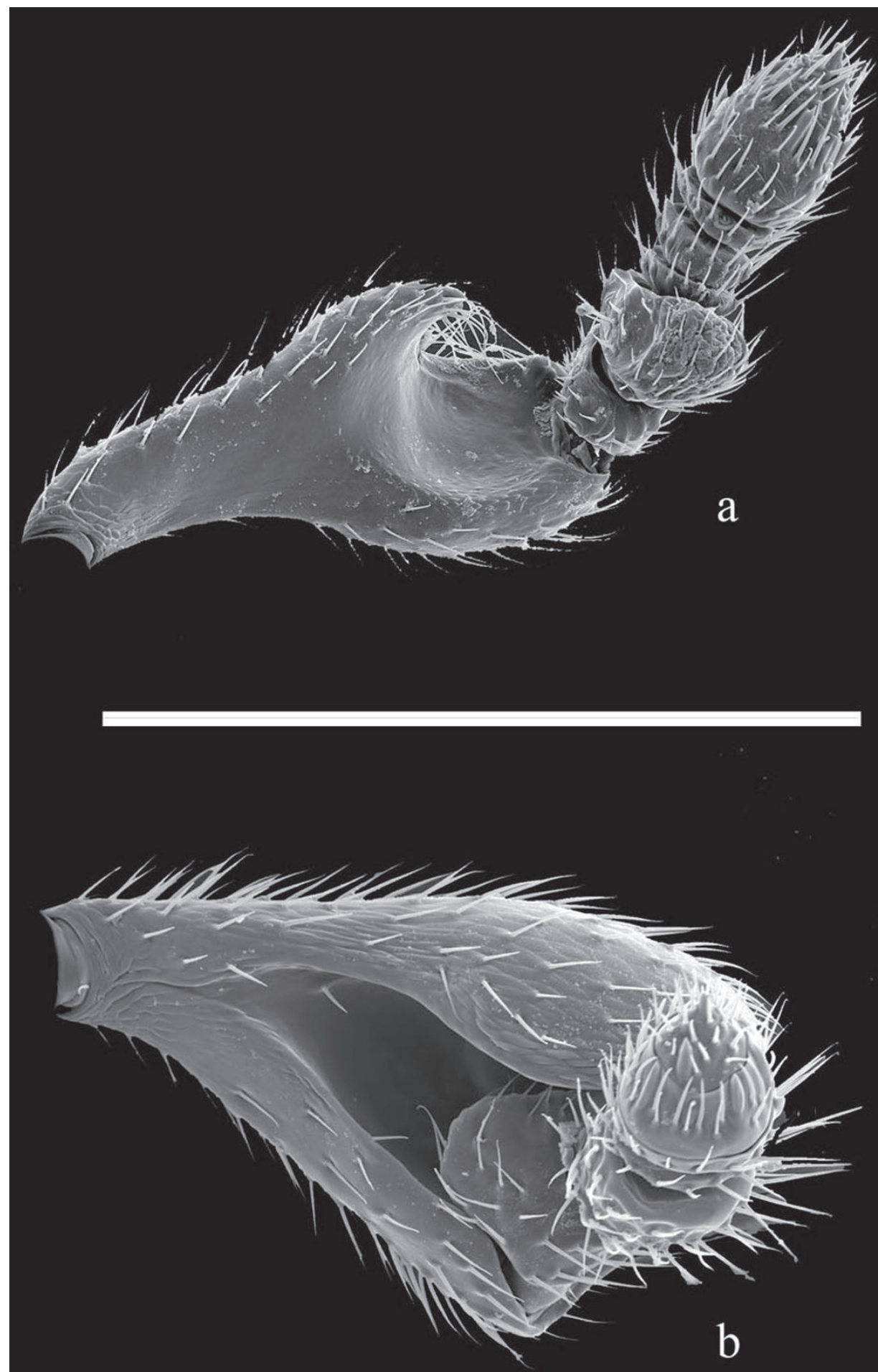

Figure 2. Male antennae of Melittobia acasta $\mathbf{a}$ and M. australica b. Scale: $0.25 \mathrm{~mm}$. 


\section{Acknowledgements}

We would like to thank Angela Sinacori (Universitá degli Studi di Palermo, Sicily, Italy) who kindly gave us useful suggestions about collecting Osmia bees and their parasitoids by using trap nests. Thanks also to Carlo Polidori (Museo Nacional de Ciencias Naturales, Madrid, Spain) for identification of S. spirifex. We are also indebted to Freder Medina for the SEM photographs of the antennae of both Melittobia species that appear in Figure 2. We greatly appreciate the thoughtful comments and suggestions given by Bob Matthews, and an anonymous reviewer, which greatly improved the submitted manuscript.

\section{References}

Assem J van den, Bosch HAJ in den, Prooy E (1982) Melittobia courtship behaviour: A comparative study of the evolution of a display. Netherlands Journal of Zoology 32(4): 427-471. doi: 10.1163/002829682X00184

Cusumano A, González JM, Colazza S, Vinson SB (2010) Behavioral responses of the parasitoid Melittobia digitata to volatiles emitted by its natural and laboratory hosts. Entomologia Experimentalis et Applicata 136: 301-307.

Dahms EC (1984a) Revision of the genus Melittobia (Chalcidoidea: Eulophidae) with the description of seven new species. Memoirs of the Queensland Museum 21(2): 271-336.

Dahms EC (1984b) A review of the biology of species in the genus Melittobia (Hymenoptera: Eulophidae) with interpretations and additions using observations on Melittobia australica. Memoirs of the Queensland Museum 21(2): 337-360.

González JM, Matthews RW (2005) An annotated bibliography of Melittobia (Hymenoptera: Eulophidae). Caribbean Journal of Science, Special Publication 8: 1-41.

González JM, Matthews RW (2008) Female and male polymorphism in two species of Melittobia parasitoid wasps (Hymenoptera: Eulophidae). Florida Entomologist 91(2): 162-169. doi: 10.1653/0015-4040(2008)91[162:FAMPIT]2.0.CO;2

González JM, Terán JB (1996) Parasitoides del género Melittobia Westwood (Hymenoptera: Eulophidae) en Venezuela. Distribución y hospederos. Boletín de Entomología Venezolana (N.S.) 11(2): 139-147.

González JM, Matthews RW, Vinson SB (2008) Distribution and host records of Melittobia (Hymenoptera: Eulophidae) from Mexico. Revista Mexicana de Biodiversidad 79: 529-531.

González JM, Terán JB, Matthews RW (2004) Review of the biology of Melittobia acasta (Walker) (Hymenoptera: Eulophidae). Caribbean Journal of Science 40(1): 52-61.

Holm SN (1960) Experiments on the domestication of humble bees (Bombus Latr.), in particular B. lapidarius and B. terrestris L. Royal Veterinary and Agricultural College of Copenhagen, Yearbook 1960: 1-19.

Holm SN, Skou JP (1972) Studies on trapping, nesting, and rearing of some Megachile species (Hymenoptera, Megachilidae) and on their parasites in Denmark. Entomologica Scandinavica 3(3): 169-180. doi: 10.1163/187631272X00274 
Incalterra G, Iapichino G, D’Anna F, Sinacori A (2003) Influences of different pollinators on winter melon Brown under polyethylene tunnel. Acta Horticulturae 614: 297-299.

Maeta Y (1978) A preliminary study on the physical control of Melittobia acasta (Walker) by cold treatment (Hymenoptera: Eulophidae). Bulletin of the Tohoku National Agriculture Experiment Station 58: 211-229.

Matthews RW, González JM (2008) The acasta conumdrum: polymorphism and taxonomic confusion within the parasitoid genus Melittobia (Hymenoptera: Eulophidae). Zootaxa 1854: 45-54.

Matthews RW, González JM, Matthews JR, Deyrup LD (2009) Biology of the parasitoid Melittobia (Hymenoptera: Eulophidae). Annual Review of Entomology 54: 251-266. doi: 10.1146/annurev.ento.54.110807.090440

Rasmont P, Coppée A, Michez D, Meulemeester T de (2008) An overview of the Bombus terrestris (L. 1758) subspecies (Hymenoptera: Apidae). Annales de la Société Entomologique de France (nouvelle série) 44(1): 243-250.

Schmid-Egger C (2003) New records of "Sphecidae" (Hymenoptera: Sphecidae \& Crabronidae) from Sicily (Italy) and Malta. Linzer Biologische Beiträge 35(2): 747-762.

Schmieder RG (1933) The polymorphic forms of Melittobia chalybii Ashmead and the determining factors involved in their production (Hymenoptera: Chalcidoidea, Eulophidae). Biological Bulletin of the Marine Biological Laboratory, Woods Hole 65: 338-352. doi: $10.2307 / 1537183$ 